\title{
Det skønne ideal. Skulptur og form i Antikken
}

\section{MARIANNE MARCUSSEN}

I nden for æstetisk forskning er det min fornemmelse, at det i de sidste årtier har været vanskeligt nærmere at præcisere dens indhold og grænser. Derfor har de emner og begreber, der tidligere har været grundigt gennemreflekterede stået over for at skulle omdefineres og reflekteres på ny for fremtiden.

Det forekommer mig vigtigt, at rationale, empiri og historieforståelse får en prioriteret plads i denne sammenhæng. Det afgørende er derfor en kontinuitet, dels tilbage til den klassiske æstetik, dels fremefter mhp. en moderne vurdering af æstetikkens plads i rækken af forskningsfelter.

Dit institut, Göran Sörbom, Institutionen för Estetik i Uppsala, hvor seminaret Estetiken infor framtiden blev holdt i november I999, kan forhåbentlig også i fremtiden løfte denne opgave. Du har holdt den æstetiske forskning i live på en fornem måde og har interesseret dig for æstetikken både i klassisk og moderne forstand. ${ }^{x}$

Derfor er mit indlæg nu, som hele seminaret, en hyldest til dig, selvfølgelig må man tilføje, og jeg vil tillade mig at dykke ned i et af de områder, hvor du har bidraget med en interessant æstetisk dialog med historien: nemlig dialogen med den græske, antikke kunst. Du er også hele tiden med i denne tekst, som en dialogpartner, ved at blive refereret. I denne sammenhæng vil specielt dine overvejelser over forholdet mellem en beskuers synsposition i forhold til den fysiske placering af skulptur og begrebet det levende i græsk filosofi blive emnet for denne dialog. ${ }^{2}$

I. Seminaret Estetiken inför framtiden blev afholdt i Uppsala den 18 . til $2 \mathrm{I}$. november 1999 . Jeg har ønsket at bibeholde den direkte tale til professor Göran Sörbom i denne artikel, således at "du"formen er formuleret med vilje. Selve foredraget havde - dette til trods - en mere uformel karakter. Det forhold, at æstetikken er svær at afgrænse, viste sig med al tydelighed ved XIV International Congress of Aesthetics, Aesthetics As Pbilosopby, i Ljubljana I 998.

2. Den artikel af Göran Sörbom jeg særligt henviser til er "Den grekiska bildrevolitionen", Annales Societas Litterarum Humaniorum Regiae Upsaliensis. Kungl. Humanistiska Vetenskapssamfundet 


\section{Om det skønne ideal: mandsfiguren}

I filmen Abernes Planet, tager de to mænd i slutscenen afsked med abedronningen, der taler et perfekt engelsk. De har fået et fint forhold til hende, selv om de to mennesker har været spærret inde i bur. Nu skal de slippes ud i det ukendte, hvor de om lidt skal møde toppen af Fribedsgudinden begravet i sand. Afskeden er kærlig - det gælder kysset - hun vil godt modtage det, men der er et forbehold, for som hun siger: "Hvis bare ikke I var så forfærdelig grimme". ${ }^{3}$

Nu har vi allerede før på filmen set de to menneskemænd - stort set in the nude - og de er, efter mine begreber i hvert fald, form-skønne.

Mandsnøgenheden er ret vanskelig at møde i moderne visuel kultur, hvorimod kvindenøgenheden er så almindelig at den invaderer hvert eneste hjem dagligt gennem film, reklamer og TV, inkluderet følelsesafstumpet voldsporno.

Men, selv om mandsnøgenheden langsomt kryber ind i vor billedverden, er der en del (mande)mennesker man ikke $i$ vor tid ser in the nude, faktisk ikke under nogen omstændigheder, f.eks. præsident Clinton. Han er simpelthen for kendt. Man kan unægtelig være nysgerrig på det punkt, især efter alle hans pikante skandaler. Men det er vanskeligere at opfatte f.eks. forhenværende præsident Nixon eller kansler Kohl som form-skønne, og man ville næppe have nogen overdreven nysgerrighed mht. at få vist dem afklædte. Hvis vi derfor ved hvilken mand der vises på et billede, vises han ikke nøgen. Identiteten kræver klæder.

Man kan argumentere, at kendte kvinder ofte jages i den anledning, men der skal ikke balanceres videre på denne tanke i feministisk teori, hvor der vil være en lang række anskuelser omkring anonymisering af kvinder $i$ det hele taget, og dermed en lang række sociologiske aspekter af denne tankegang som ikke er mit ærinde her.

Dog, disse indledende bemærkninger, fordi det, ud fra en tolkningsteoretisk vinkel øjensynligt er vanskeligt, i vor tid, at tillægge det antikke nøgne mandsmenneske, en bestemt jordisk identitet. Og i og med vi kan have denne vanskelighed, og ikke har en moderne billedkultur, der øjensynlig kan abstrahere omkring dette, har vi nok heller ikke en præcis nøgle til en "einfühlung" omkring de nøgne antikke mandsfigurer.

i Uppsala Årsbok, 1 997, 37-63; se også Göran Sörbom, "'A Lost Art'. Optical Refinements in Greek Classical Marble Sculpture", i Richard Woodfield, ed., Gombrich on Art and Psycbology (Manchester r 996), r 56-r 70.

3. Det er lang tid siden jeg har set filmen, så derfor er anførelsestegnene ikke et faktisk citat, men som jeg erindrer det. 
Der er blevet talt så meget om væddekampe i den antikke kultur: man var nøgen under sportskampe. Det må vi tro er sandt, men i moderne kultur er man ikke afklædt under sportskampe. Enten kan vi ikke se formålet med nøgenheden eller vi ville formentlig opfatte den som pinlig og grænseoverskridende, måske anstødelig eller jæunt hen latterlig.

Man provede i 6oerne og 7 oerne forskellige steder $i$ verden med nøgenhed på scenen. Balletten Dødens triumf på Det kongelige Tea-

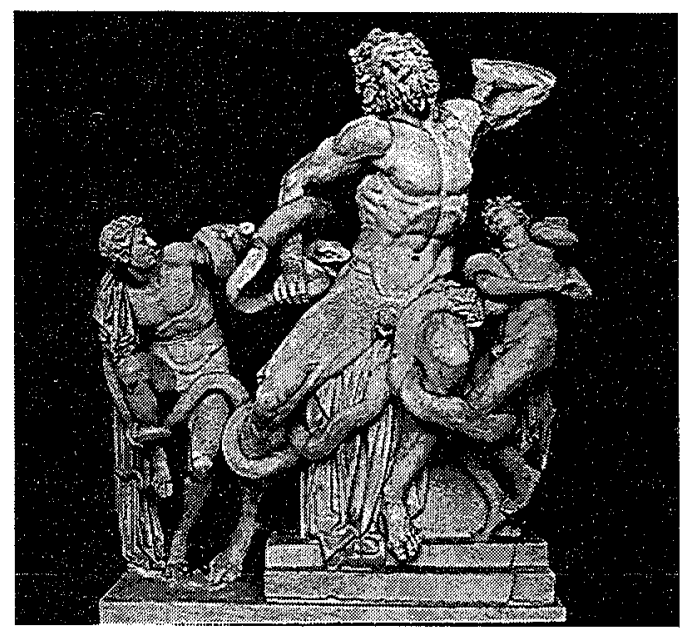

Fig. I. Laokoon, hellenistisk eller fra romersk kejsertid? Vatikanet, Rom. ter i København er et eksempel. Mænd og kvinder dansede nøgne - eller klædte sig af - men det var måske ikke nøgenheden i sig selv, men afklædningen der var temaet - og måske var denne passage af forestillingen kunst eller måske var det bare borgerlig, statsstøttet pornografi.

Men, hvorom alting er, nøgenheden har en kulturhistoriografi, den er med i vor æstetik og dermed i vor billedkunst.

\section{Det skonne ideal som begreb og form}

Det, at vi har et skønhedsbegreb, som er et abstraktum, der fungerer som referentiale $\mathrm{i}$ beskrivelse og tolkning af nøgenheden i den bildende kunst gennem tiderne, kan også fungere som referenceramme for kropsskønheden for de levende. Det er en skematiseret nøgenhed, der kan ligne en virkelighed, men ikke hverken er statistisk eller virkelig, men konstrueret ud fra forskellige typer af principper omkring forhold mellem kroppens dele: arme, hænder, fødder, brystkasse, hofter etc. ${ }^{4}$

Der kan være varianter inden for alle perioder. Den ældre mand f.eks. kan være lidt mere knoklet end den yngre som i Laokoon-gruppen, men vi har ikke her nået

4. Sigrid Braunfels, m.fl., Der "Vermessene" Mensch (München I 973); Nikolaus Pevsner, Academies of Art. Past and Present (Oxford 1940); se også, Torsten Weimarck, Akademi och Anatomi (Stockholm I 996). 
en smertegrænse for det skønne, som med en Silen, hvor den er langt overskiredet.

Hvad er dette skønne ideal til for? I virkelighedens verden formentlig til at flytte rundt på forholdet mellem mænd og kvinder - forplantning - darwinistisk udvælgelse - i vidt omfang friholdt fra juridisk ræsonnement, men 'derfor ikke nødvendigvis adskilt fra et moralsk.

Det skønne ideal kan få tillagt moralske værdier, șom teoretisk kan være virkelige, men ikke nødvendigvis realistiske. Og hvorledes vi end vender og drejer problematikken i europæisk kunst, vil det skønne og det gode, måske også

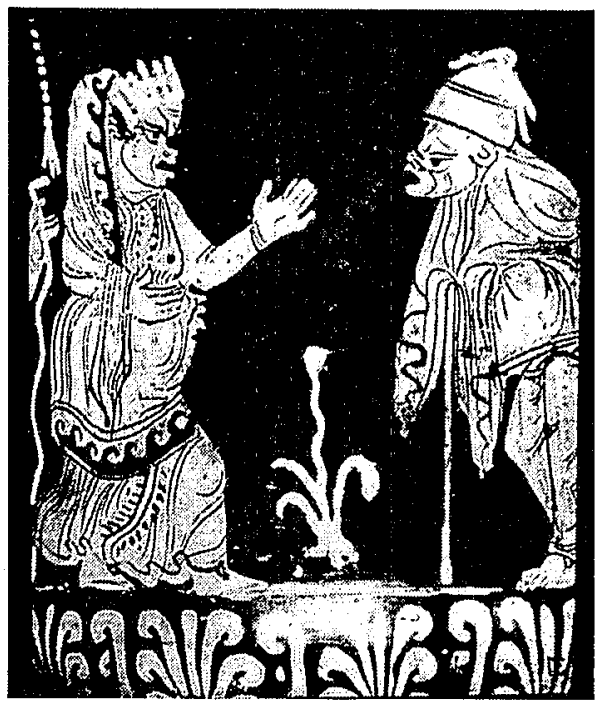

Fig. 2. Teaterscene med groteske figurer. Vasemaleri, 3. årh. f.Kr. det moralske, være besynderligt og knudret sammenvævede. En af de mere patetiske og absurde håndteringer af dette ideal var indlagt i Pioneer rumsonden, et forhold som Ernst Gombrich har gjort opmærksom på. ${ }^{5}$

Det skønne ideal kan kobles til en bestemt type overlevelse eller guddommeliggørelse, når vi ser på det som historiografisk fænomen. Det kan ræsonneres som begreb og indlægges, synligt, $i$ et billede.

Det formål der kan være med at billedliggøre det kropsligt form-skønne, er at særligt udvalgte mennesker $\mathrm{i}$ historien skal kunne genkendes i deres billede, f.eks. Trajan eller Napoleon. Det er det form-skønne - formen i sig selv - der skal definere det særlige og på den måde vil det, denne skønne form tager ophold $\mathrm{i}$ - sjælen eller sindet - blive ideal skøn $\mathrm{i}$ teorien. Det kan enten være et guddommeliggjort menneske eller en guddom i menneskelig skikkelse: Christus, Maria, Augustus, Zeus, Artemis, Venus - eller - Tarzan og Schwarzenegger?

\section{Det skønne ideal og det levende}

Det, du viser Göran, i dine artikler om den græske skulptur er, at der består et forhold mellem især mandsfremstillingen - det skønne ideal i skulpturel form som en idealisering af det levende - og begrebet om det levende. I den græske

5. Ernst Gombrich, Det visuelle billede (Odense r979), 65. 


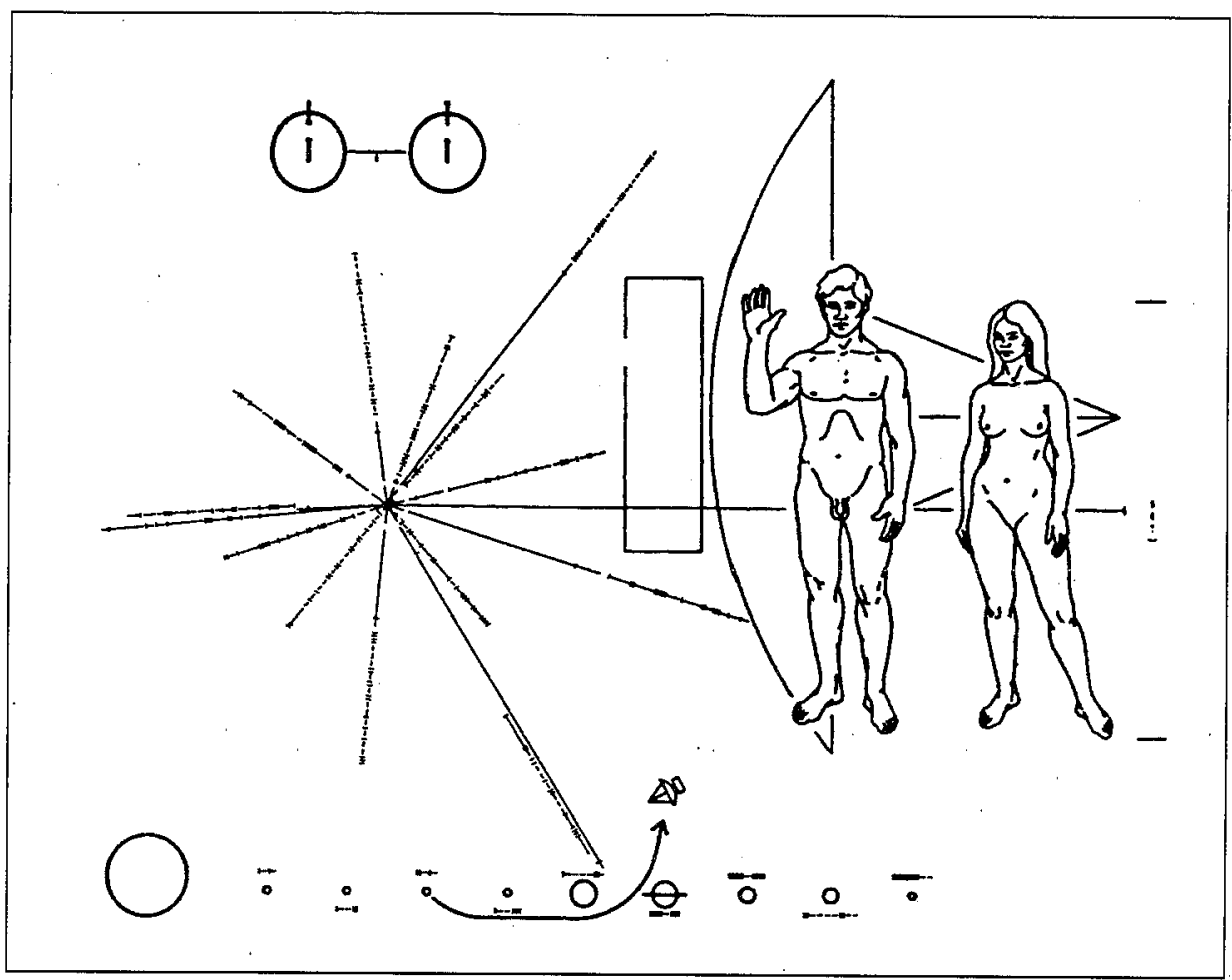

Fig. 3. Billede indlagt i rumsonden Pioneer. Ernst Gombrich, Det visuelle billede (Odense 1979), 65 .

antik kødeliggøres formen, som Julius Lange ville udtrykke sig (ca. I 880): man fornemmer "kødduften", når man betragter skulpturerne i Parthenongavlene, men samtidig repræsenterer skulpturen det guddommelige, skønne ideal. ${ }^{6}$

Du beskriver, ud fra din indsigt i og forståelse af begrebet det levende, hvorledes det forbindes med synet eller perceptionen, og på denne måde synliggøres for et moderne blik. Men kun, således som jeg forstår det, hvis vi forholder os både til det antikke og det moderne perceptionsbegreb.

$V_{1}$ må antage, at perceptionen har en vis historisk stabilitet inden for visse aspekter af den. Denne diskussion må hvile i denne sammenhæng. ${ }^{7}$ Vi må også

6. Julius Lange, "Billedkunstens Fremstilling af Menneskeskikkelsen i den græske Kunsts første Storhedstid", Det Kgl. Videnskabernes Skrifter 6. Rekke, bistorisk og filosofisk Afd., IV, 4, 230 (70).

7. Her er det vigtigt at skelne mellem naturlig perception og billedperception - uanset man ikke kan trække skarpe grænser. Der vil derfor være forskellige holdninger til de to ting i diverse bøger om perception, set ud fra psykologiske eller billedhistoriske/teoretiske sammenhænge. En moderne gennemgang af de psykologiske aspekter se David Hubel, Eye, Brain, and Vision, Scientific American Library ( 988 ; New York 1995). 


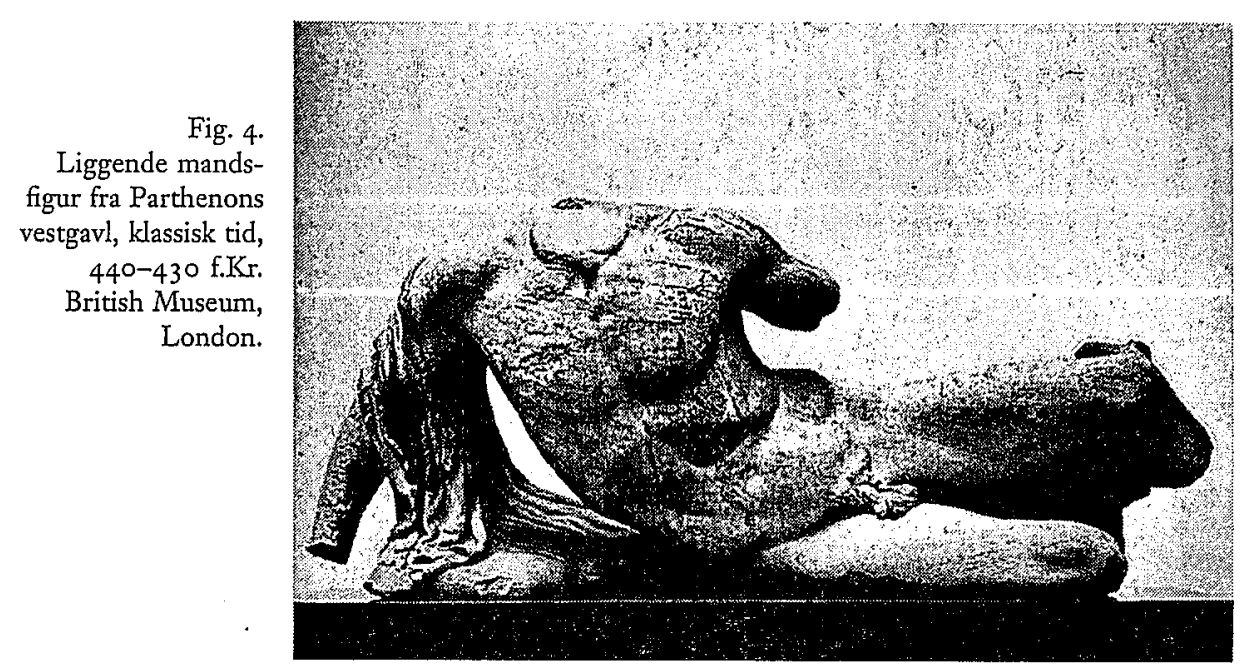

antage at der eksisterer regler for fremstillingen af det levende i begrebet den skønne form i den antikke græske kunst.

Denne kobling mellem det skønne ideal og det levende kan selvfølgelig foretages på mange måder gennem historien som Kenneth Clark har vist i sin forunderlige bog The Nude. Platons ræsonnement om ægypterne er i denne henseende interessant, idet han siger, at når ægypterne een gang havde bestemt hvorledes billederne (eller musikken) skulle materialiseres, blev disse regler (for frembringelsen) fremvist i helligdommene - og det var ikke tilladt at fravige dem. ${ }^{8}$

Det er dokumenteret, formentlig ud fra et kendskab til disse regelsæt, ved historikeren Diodorus Siculus på Cæasar og Augustus' tid, at en figur, udført efter det ægyptiske system, af to billedhuggere på hvert sit sted, kunne sammenføjes, fordi reglerne for deres hugning var så præcise. Her må det påpeges, at dette er muligt formentlig alene ud fra den forudsætning, at ganske bestemte, formentlig enkle, numeriske, proportionssystemer samt en meget præcis håndtering af den rette vinkel ( $9 \circ$ grader), har været grundlaget. Dette medfører frontalitet både i 2-og 3-dimensional afbildning, hvilket ikke er det samme som at sige at kunstværkerne mangler rumlig illusion for synet/blikket/forstanden. ${ }^{9}$

8. J. J. Pollitt, The Ancient View of Greek Art (New Haven og London I974), I 26. For en dansk fortolkning i relation til rumgengivelsen, se Birgitte Bøggild Johannssen og Marianne Marcussen, Rumperception og Rumkonstruktion. Kildeskrifter til optikkens og linearperspektivets bistorie $i$ Vesteuropa fra antikken til renessancen (København: Institut for Kunsthistorie, I978), I 2 ff.

9. Sörbom, "Den grekiska bildrevolutionen", 38. Pollitt, Ancient View, I 26. Hvorledes den rette vinkel har været så præcist etableret $i$ egyptisk historie er der ikke fuldstændig enighed om. Traditionen for at fastlægge denne vinkel synes at være gået mere eller mindre tabt $\mathrm{i}$ europæisk middel- 
Dette system ændres radikalt i græsk kunst. Formelt dannes en symmetria, dvs. ideale forhold, eventuelt talforhold eller geometriske proportioner, i skulpturerne. ${ }^{\text {I0 }}$ Skulpturerne får en fremtrædelsesform, hvor frontalitetet ophæves, dvs. har stor variation, og en moderne tolkning vil tillægge denne variation en "synsrealisme". Dette skift sker sideløbende med grækernes interesse for at forske i synet og perceptionens art, samtidig med at der sker en total ændring af matematikken. Hvad det kan betyde for kunsten vil blive diskuteret til sidst.

\section{Det skønne ideal i filosofi og kunst}

Vi kan få den opfattelse at hverken Platon eller Aristoteles havde sympati for den kunstneriske udvikling, men spørgsmålet er vel om de taler specifikt om kunstværker eller de bruger dem, som eksempler, for at vende et filosofisk problem. ${ }^{\text {Ir }}$ Set ud fra den distinktion mellem abstrakt matematik og anvendt matematik, vi finder hos Aristoteles, kan man måske åbne en breche for at nuancere denne opfattelse. ${ }^{\mathrm{xz}}$

Du har fokuseret på den græske, antikke kunst, især perioden omkring overgangen fra tidlig klassisk til klassisk kunst i tiden fra Olympiagavlene til omkring Parthenonskulpturerne, dvs. i perioden fra ca. 460 til 430 . Vi må her anerkende at den græske kunst allerede havde taget springet fra ægyptisk påvirket til klassisk og at de to filosoffer dermed optræder som (kunst-) historikere. Og når Euklid, der formentlig levede omkring 300 introduceres i diskussionen neden for, er Euklid's Elementerne og Optikken derfor ikke et videnskabeligt forbillede for kunstnerne, men indskriver sig $i$ en verificerende fase, en dialog kunne man kalde det, af en udvikling i kunsten vi kan se finder sted over en periode på ca. I 50 år.

alder. Årsagerne til dette kan diskuteres, men forf. arbejder pt. på en nærmere fastlæggelse af dette problemkompleks inden for projektet The Artist's Share. Se iøvrigt f.eks. David M. Burton, Burton's History of Matbematics. An Introduction (I991; Dubuque, IA, I995), 3 I-70, og Gay Robbins, Proportion and Style in Ancient Egyptian Art (London I994).

ro. Braunfels, Der "Vermessene" Mensch, og Ernesto Grassi, Die Theorie des Scbönen in der Antike (Köln I980); Pollitt, Ancient View, 2 ff.

I r. Bøggild og Marcussen, Rumperception og Rumkonstruktion, I I ff.

I 2. Bente Kiilerich siger: "Når Polyklet ifølge Plinius (34.65) udførte sine statuer af mennesker, som de 'var', men Lysippos udførte sine, som de 'syntes at være', er denne udtalelse muligvis en hentydning til, at Polyklet benyttede alethine symmetria, faktiske proportioner, medens Lysippos benyttede phainomene symmetria, optiske proportioner." Bente Kiilerich, Gresk Skulptur, fra dadalisk til bellenistisk (København I 989), 250.

Som det fremgår af den tankelinie, som jeg har fremlagt her, må fortolkningen sikkert kunne 
Fig. 5 .

Detalje af frisen på Parthenon, klassisk tid, ca. 438 f.Kr.

British Museum,

London.

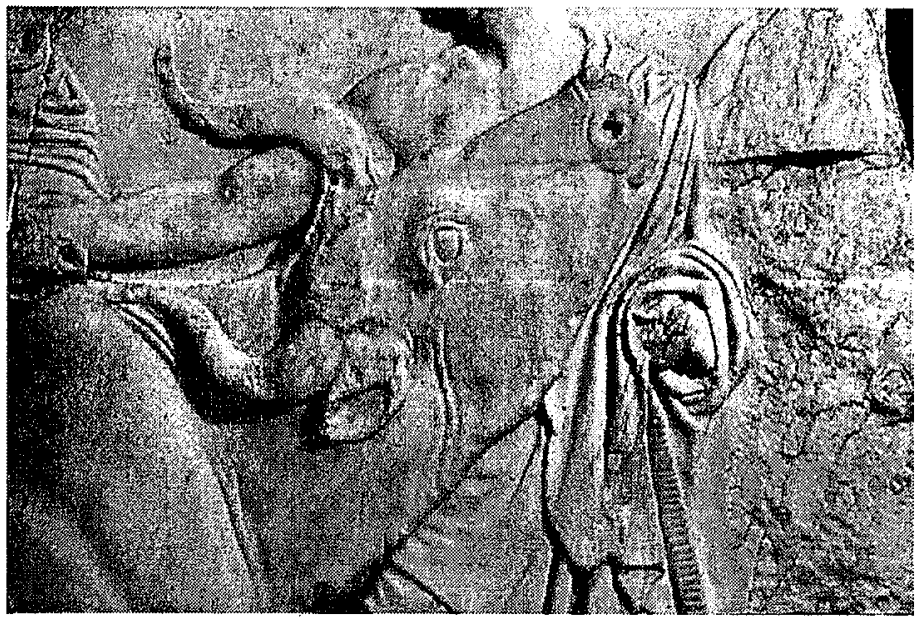

Og fordi du har så grundigt et kendskab til den græske kunst, filosofi og kultur går du i rette med museumsopstillingen. Denne er, så vidt jeg ser det, altid artificiel - uanset man, f.eks. i Berlin - har forsøgt at stille Pergamonaltret op så vi făr en eller anden illusion om at vi kan kompensere for museumsopstillingen $i$ forhold til virkeligheden. Vi ser persiske tæpper hængt på vægge og mange andre artificielle betragtningsmåder. Det er vi blevet vænnet til siden The Museum Age begyndte i I 700-tallet og måske har dette faktum en vis betydning for udviklingen af de formelle analyser i kunsthistorien omkring I $9 \circ 0$ og dermed for en fortolkning af det skønne ideal. ${ }^{13}$

Men mange skulpturer er stadig in situ, bl.a. på Parthenon og derfor kan vi slutte fra disse kunstværker til mange andre, der er opstillet i museerne. Men problemstillingen er ikke helt så enkel, som du har påpeget. ${ }^{\mathrm{I}}$ Du bidrager, ved at sammenknytte den formelle analyse af kunstværkerne med de filosofiske begreber, til at forstå hvad det er vi skal se efter. Man kan derved gå tæt på kunstværkerne i museerne og ræsonnere over deres fysiske fremtrædelsesform også i tilfælde, hvor der ikke er en nærmere dolumenteret viden om deres oprindelige placering.

forbindes til den aristoteliske distinktion mellem abstrakt og anvendt matematik - og derfor være et tydeligt tegn på en dialog mellem kunsten og de eksakte videnskaber i denne periode. "Aristotle. Perception and Depiction in the Early Florentine Renaissance", til akterne fra konferencen The New Aristotle, Forum for Renaissance Studies, University of Copenhagen, 23-25 april I 998, 4I-58.

I3. Man kan pege på wienerskolens formalister f.eks. Alois Riegl, der arbejdede på bogen Stilfragen, I 893 under inspiration af arbejdet med tekstiler. Han var en overgang ansat på Österreichisches Museum für Kunst und Industrie. Se Marianne Marcussen, "'Nicht alles ist zu allen Zeiten möglich"', Nordisk estetisk tidskrift I $_{4}$ (I995), 5 I-68.

I4. Sörbom, "Den grekiska bildrevolutionen", $40 \mathrm{f}$. 
Det er qua begrebet det levende og dets forhold til billedliggørelsen af det skønne ideal i græsk filosofisk forstand, du kan udpege en række forhold af betydning for moderne tolkninger af græsk kunst. Ikke at der ikke allerede eksisterer meninger derom - de er vel nærmest utællelige - men du vil tæt på kreativitetsfasen $\mathrm{i}$ kunstnerens arbejde vis à vis beskuerens kulturelle tankesæt for dermed at gøre det skønne ideal og dets levendegørelse tydelig for moderne tankegang.

Du fremholder otte ting hos Xenophon, som har betydning og som jeg resumerer meget sammentrængt: at billeder fremstiller synlige ting - eller gør ting synlige, at de kan fremstille ide-

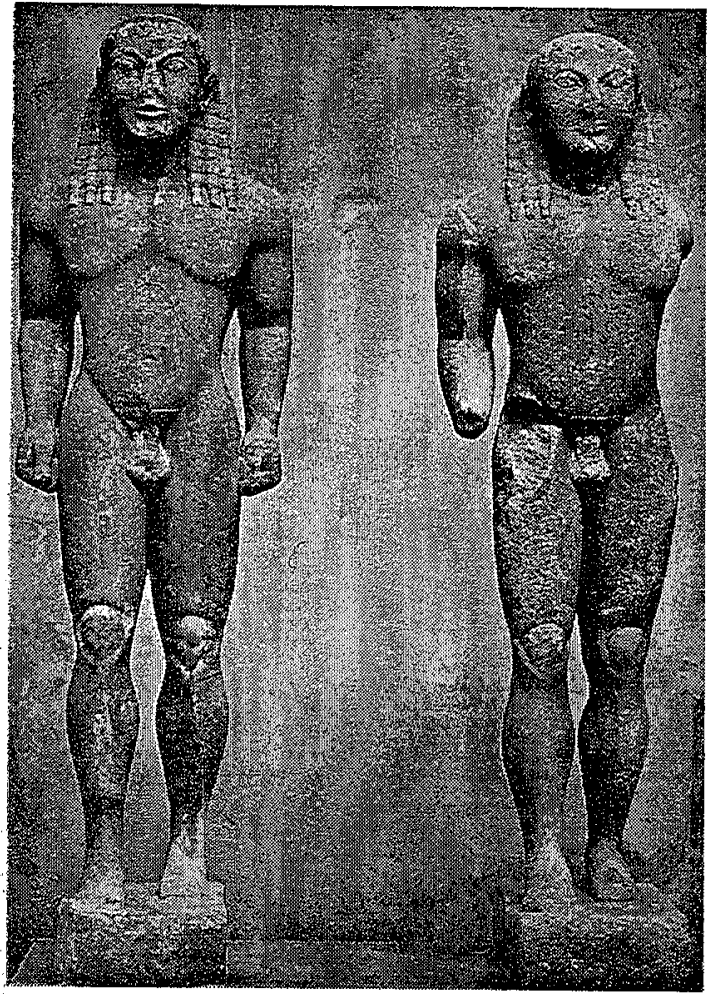

Fig. 6. Kleobis og Biton, arkaisk tid, ca. 590 f.Kr. Museet i Delphi. ale synlige ting, som er særligt skønne, men sjælen kan kun udtrykkes ved kroppens ageren.

Figurer bør netop fremstilles således, for at skabe indtryk af liv, dvs. der skal udtrykkes bevægelse og stemning $i$ billeddannelsen. Og billederne, således forstår jeg det, må endda vægte det levende højere end det skønne. ${ }^{\text {Is }}$

Ser vi så det levende som grækerne så det eller fortolkede det ? Logisk set nej, men historikeren må have. den overbevisning, at man kan tolke ældre kunst og videnskabelige tekster loyalt.

Det skønne ideal skal altså kunne ses som levende i billedet, også for os. Her er, som nævnt, stor overensstemmelse med Julius Langes opfattelse - et forhold som bestemt ikke må underkendes, hans store indsigt i og kærlighed til kunsten især omkring Partbenonskulpturerne taget $\mathrm{i}$ betragtning. ${ }^{\mathrm{i}}$

I 5. Ibid., $44 \mathrm{f}$.

I6. Lange, "Billedkunstens Fremstilling af Menneskeskikkelsen", 230. 
Det skønne ideal eksisterer - det findes - som begreb og som materialiseret form - altså både i det filosofisk abstrakte ræsonnement - og i kunsten, som konkret form. Det levende har samme tilknytning: som begreb i filosofien og som form i skulpturen.

Hvis vi anskuer det skønne ideal $\mathrm{i}$ kunsten, som det visualiserede, kan man spørge: hvem har stået model? Er en model nødvendig eller må vi konstatere med lærdommen fra den græske kunst, at det er et sammensat fænomen? ${ }^{17}$ Altså at ingen jordisk er fuldkommen skøn, selv om det billedskønne menneske $i$ billedet forestiller et menneske. $\mathrm{Og}$ bille-

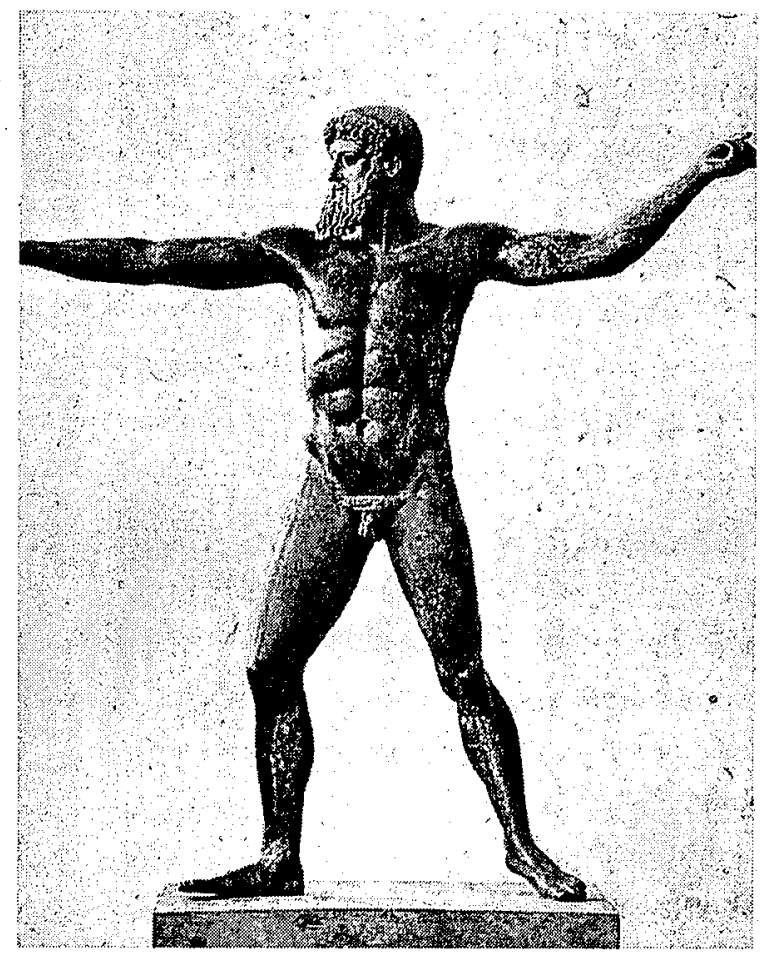

Fig. 7. Poseidon (Zeus?) fra Kap Artemision, tidlig klassisk tid, ca. 470-60 f.Kr. Nationalmuseum, Athen.

det kan blive smukt og synes levende uden at der eksisterer en faktisk model i det hele taget, der andet end i visse henseender kan ligne det skønne ideal.

Den praksis at omforme en model, (et faktisk eksisterende menneske) i overensstemmelse med en forestilling om det idealt skønne, som det udformes i den antikke, græske kunst fortsættes gennem hele den vesterlandske, akademiske tradition. ${ }^{18}$

Det billedskønne er dermed en beregnet størrelse, men hvilken beregning? Eller snarere hvilken slags beregning? Her er det muligt at indlede en diskussion om forholdet mellem målte størrelser, som efter målebånd eller som geometriske proportioner og de estimerede størrelser, der eksisterer for synet.

Kenneth Clark har formuleret sig således:

7. Pollitt, Ancient View, I 5 ff. og I 27.

I8. Se Braunfels, Der "Vermessene" Mensch; Pevsner, Academies of Art; og Weimarck, Akademi ocb Anatomi. 
This feeling, that the spirit and body are one, which is the most familiar of all Greek characteristics, manifests itself in their gift of giving to abstract ideas a sensuous, tangible and, for the most part, human form. ${ }^{\text {I9 }}$

Der er derfor ingen tvivl om at det skønne ideal eksisterer, som abstrakt referenceramme for vore domme om den skønne krop, det være sig den afbillede eller den levende.

Og med Clarks ord - kunsthistorikerens - er en definition af det skønne ideal en påpegning af bestemte formelle aspekter af en billedligt fremstillet krop $\mathrm{i}$ en bestemt historisk sammenhæng. Her må Clark også tage matematikken i ed. ${ }^{20} \mathrm{Og}$ det, der kan læres af den er, at i den, som i æstetikken, tages en definition ikke for evigt given. Dette til erindring, fordi man almindeligvis har en forestilling om matematikkens entydighed og sikkerhed, som er afgjort forskellig fra æstetikkens langt mere åbne definitioner eller indkredsninger. Men matematikkens definitioner er ikke meget "bedre" end kunstens definitioner - de har en anden form. Alligevel har matematikken meget at sige æstetikken - og med dette udsagn er Clark enig uanset han desværre ikke i The Nude forfølger denne tankegang ind i græsk naturvidenskabs historiografi. Det skal forsøges kommenteret til sidst.

\section{Om at se det skønne ideal}

Man kan opfatte definitioner på hvad kunst - eller det kunst-skønne er - som typer af samtalesystemer om noget vi kan udpege - og faktisk kan opnå en god del konsensus om. Opbygningen af disse samtalesystemer er en kompleks og historiebunden proces. De skal ikke rubriceres under det private. De må have en vis almen gyldighed og dermed kunne underkastes analyse gennem historien.

$V_{1}$ fælder jo hele tiden domme om det kunst-skønne og vi hævder også, med Julius Langes formulering, beskrivelsens objektivitet. ${ }^{21}$

Når de er sagt er det også korrekt at det kunst-skønne har mange boliger, bor i unika. Kunsthistorikerne udpeger det ofte det skønne uden nærmere, filosofisk argumentation, men ud fra en formel beskrivelse af et kunstværk - hvad det så kan indebære.

r9. Kenneth Clark, The Nude. A Study of Ideal Art (1956; London 1970), 2 I.

20. Ibid., I I.

2 I. Julius Lange, Om Kunstverdi ( 1876 ; $196_{3}$ ), 8. Se Marianne Marcussen, "Julius Lange og hans valgparametre i æstetikken. Et essay", Nordisk estetisk tidskrift I 7 ( I998), 79-I00. Engelsk oversættelse i International Yearbook of Aesthetics 2 (Lund 1998), 19-36. 
Den slags udsagn kan udgå fra en egentlig ganske triviel situation: når man vandrer rundt mellem nedstyrtede søjlekapitæler hvor som helst i verden - så kan man finde på at spørge om mange ting: hvordan $i$ alverden har de fået echinus cirkelformet - hvordan er mange søjler blevet ens - hvordan er skafterne blevet kurvede for at undgå at se brækkede ud - hvordan er de slebet, for med øjnene kan man se selv de mest diminutive uregelmæssigheder, hvordan spiller lyset på en overflade ved morgengry og aftentide, hvordan kan man hugge en figur ud af en sten uden fire tommeltotter eller storetæer - hvordan afbildes bevægelse? $\mathrm{Og}$, hvornår synes en skulptur levende?

Når man går mellem gavle, metoper og frisestykker på British Museum i London, kan man gå med arkæologens, filosoffens, matematikerens eller kunsthistorikerens opmærksomhed - eller alles - og erklære sig enig med John Keats da han, måske også med denne del af Parthenonfrisen in mente, skrev Ode on a Grecian Urn:

Who are these coming to the sacrifice? / To what green altar, $O$ mysterious priest, / Lead'st thou that heifer lowing at the skies, / And all her silken flanks with garlands drest? $/ 22$

Men bortset fra denne indlevede beskrivelse af et kunstværk, kan man også være nysgerrig mht. om vi kan udlede hvordan kunstneren har ønsket vi skulle se kunstværkerne. Vi kan da forholde os til en række af de forhold, der blev stillet af opgaven, som: placeringen og synspositionen.

En friskulptur er beregnet til at gå rundt om - ses fra alle sider: Kleobis og Biton eller Poseidon (?) uanset vi faktisk ikke ved hvor højt oppe de har stået, men det kan dine overvejelser måske være med at få klarhed over. Eller man kunne pege på Riacce-bronzerne, der er kom for en dag i 1972 og som måske slet ikke havde været opstillet nogen steder, før de endte på havets bund. Ses de neden fra ser de særdeles levende ud, næsten truende, hvad der måske har været meningen. Metoper, gavlfigurer og friser på græsk arkitektur sidder fast $-i$ en vis position $i$ forhold til en beskuers vàriable synspositioner, og må derfor udbrede et visuelt budskab derfra.

Da Parthenonfigurerne blev bragt til London så man dem pludselig helt tæt på, hvilket inspirerede til særlig tolkning. ${ }^{23}$ I I $950 e r n e$ blev disse værdier set som et

22. Martin Robertson, The Parthenon Frieze (London I 975), tekst ved XXXVII og afb. XL, I I $2-$ I 5 ; The Poetical Works of Fobn Keats, ed. Francis T. Palgrave (London I 889), 2 I 6.

23. Robertson, Parthenon Frieze, I 2 ff. 
skulpturelt ideal. Hvis man sammenlignede dem med f.eks. Laokoon, som man dengang anså for hellenistisk, "[havde man med Laokoon] mistet grebet om skulpturel form", som Margarete Bieber f.eks. udtrykker sig. ${ }^{24}$

Konteksten omkring en synsmåde/synsposition indgår derfor til stadighed $\mathrm{i}$ forhold til de begreber der sættes i spil omkring tolkningen.

$\mathrm{Og}$, der er dermed lagt en problemstilling ud der tager det kunst-skønne, det skønne ideal for givet, men det synes som begrebet det levende kan tydeliggøre en synsmåde for skulpturen, således at det kan formidles - også $\mathrm{i}$ en moderne museumsopstilling.

Her er vi perceptuelt på mere sikker grund: er man levende er man bevæget - eller i bevægelse -

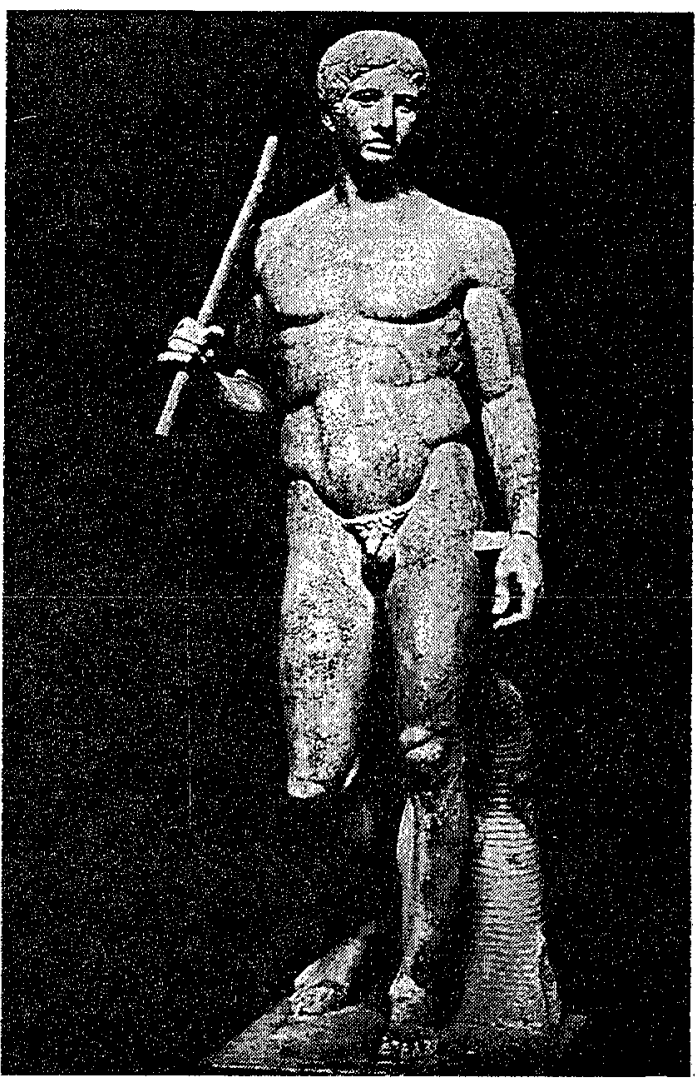

Fig. 8. Polyklet, Spydbereren, romersk marmorkopi, originalen af bronze, fra klassisk tid, ca. $460 \mathrm{f.Kr}$. Nationalmuseum, Napoli. og man har udtryk - eller udstråling. Disse fremtrædelsesformer for liv kan vi kognitivt erkende, og derfor er det sandsynligt at det også er tænkt ind ved fremstillingen af skulpturen.

\section{Det skonne ideal som skulpturel form}

Tager vi et af de berømteste eksempler på det skønne ideal, nemlig Polykleitos Spydbereren, som vi kender alene gennem romerske kopier, så virker det som den

24. Margarete Bieber, Laocoon. The Influence of the Group since Its Rediscovery (Detroit I 942), I 7 . Se iøvrigt Marianne Marcussen, "The Laokoon. Between Style and Iconography", Nordisk estetisk

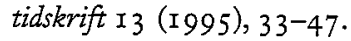


skal stå lodret, dvs. der er en lodret akse fra hoved til fod - og dermed synes det også som man har skullet se denne figurs både hoved og fødder fra en given synsposition. Man kunne derfor slutte at den ikke har stået så højt. Men, denne antagelse kan være belastet, fordi skulpturen er en romersk kopi efter et græsk forbillede. Og fordi man i romersk tid udsmykker sine huse med kopier efter græske statuer, lægger man muligvis også en anden synsvinkel ind i kopieringen for at tilpasse den et formål og en plads den ikke nødvendigvis havde i græsk tid. ${ }^{25}$

Ser vi nemlig på to græske originaler fra henholdsvis ca. $420 \mathrm{og}$ ca. 200 f.Kr.: Nike af Paionios og Nike fra Samotbrake, så ved vi at Nike af Paionios, efter dokumentation, stod på en $8,80 \mathrm{~m}$. høj sokkel. Figuren er tippet meget forover. Ligeså er Nike fra Samothrake tippet forover. Det viser, at der har været konkrete overvejelser mht. at placere figurer i forhold til veldefinerede synspositioner. Synspositionen forekommer anderledes ved Vognstyreren, der efter denne tankegang formentlig har stået lavere end de to Nike, og ser vi på Rayetbovedet er forskellen mellem det stiliserede og psykologisk distante ved frontal synsposition og det meget anderledes levende set neden fra overordentlig tydelig. ${ }^{26} \mathrm{Vi}$ kan hermed an-

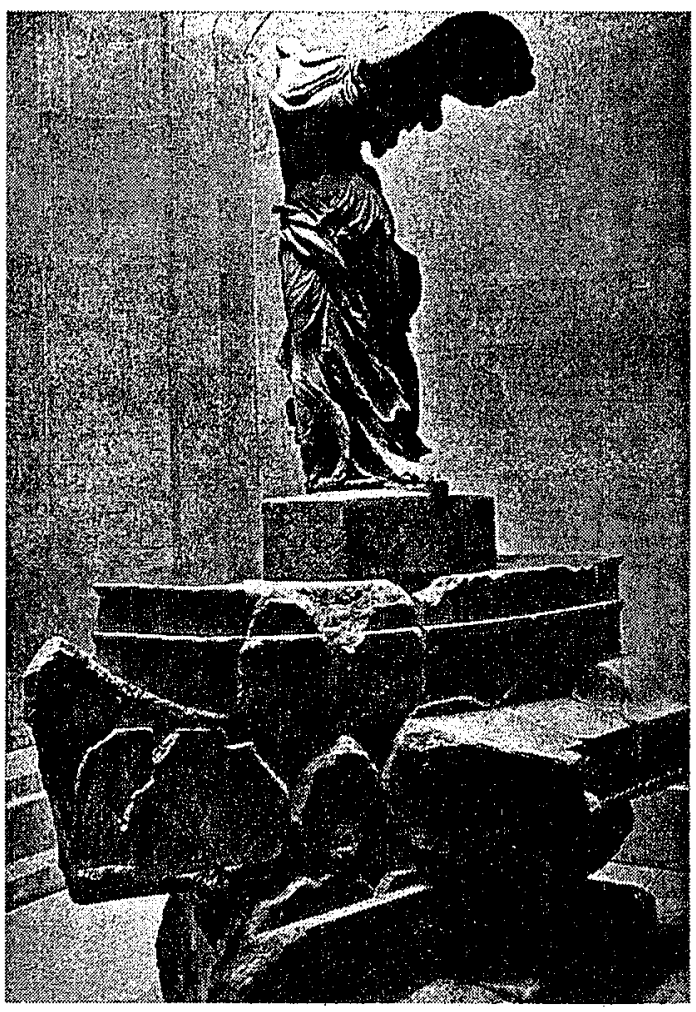

Fig. 9. Nike fra Samotbrake, hellenistisk, ca. 200 f.Kr. Louvre, Paris.

25. Friedrich Hiller siger: "Die Unsicherheit gegenüber der Masstreue der Kopien macht die Lage einer schier Hoffnungslos: Sie sind enstellt durch den Zeitgeschmack der jeweiligen Kopisten, Ungenauigkeit der Übertragung, Umsetzung in anderes Material und nachträgliche Beschädigung." Braunfels, Der "Vermessene" Menscb, 33. Se også Marianne Marcussen, Rumkonstruktioner (Kobenhavn: Institut for Kunsthistorie, 1984), 52.

26. Hannemarie Ragn Jensen har analyseret denne problemstilling, Billedbeskrivelse et redskab til billedanalyse, ed. Hannemarie Ragn Jensen og Marianne Marcussen (København: Institut for Kunsthistorie, 1980 ), tekstbind $18-25$, billedbind pl. $2-4$. 


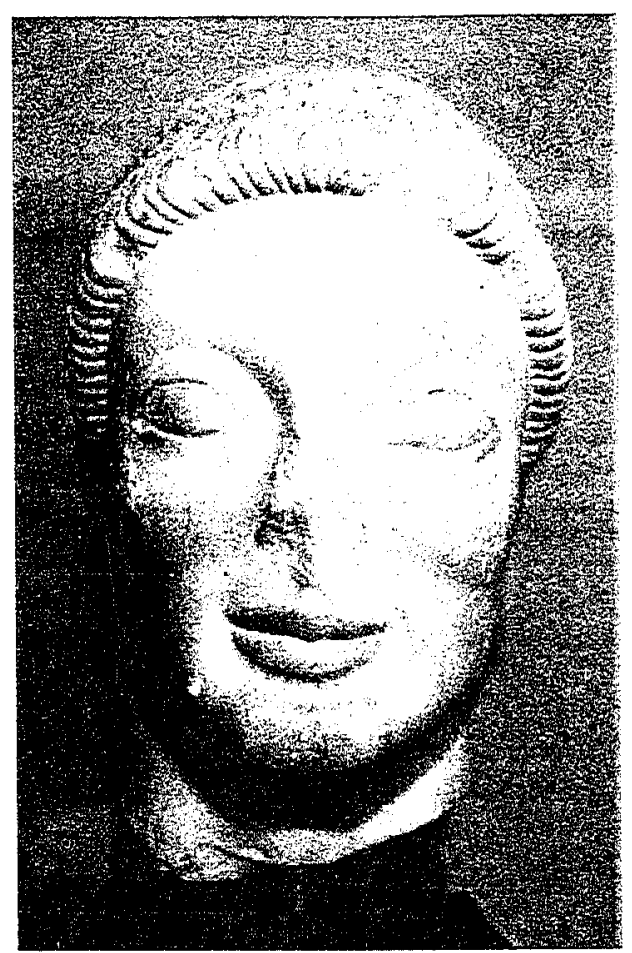

Fig. IO-r $\mathrm{I}$.

Rayetbovedet, fra to forskellige synsvinkler, arkaisk tid, ca. 540-5 I 5 f.Kr. Ny Carlsberg Glyptotek, Kobenhavn, fotograferet af Peter Schandorf.

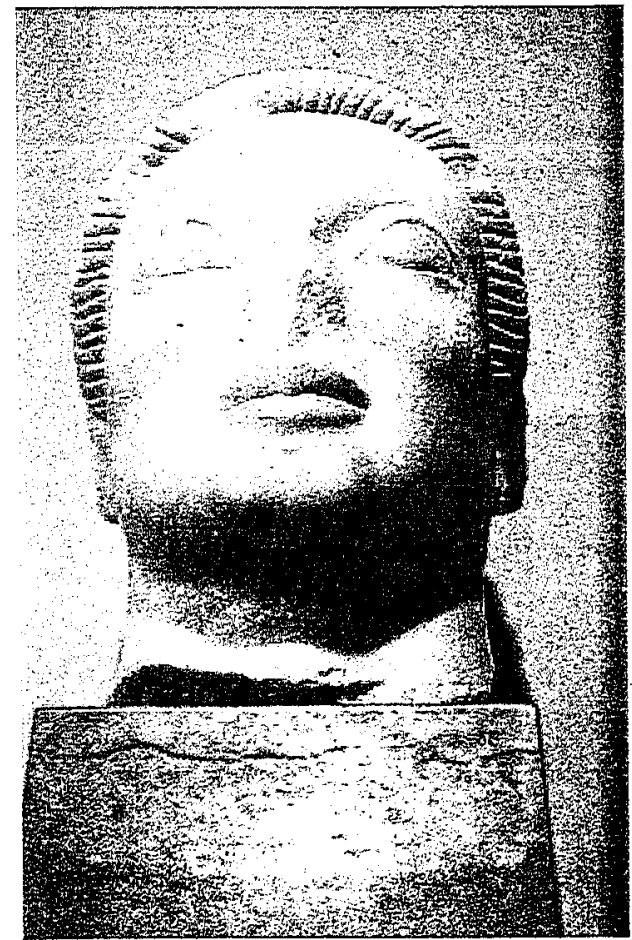




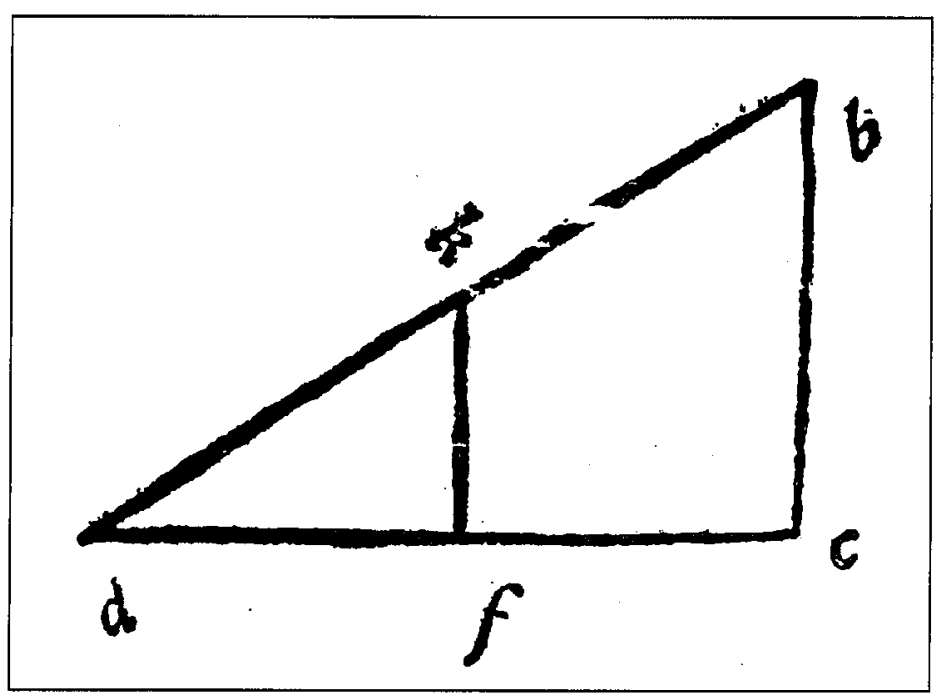

Fig. I 2 .

Illustration af Euklid's sæetning om måling i Optikken, Basel I 546, der siger, at vi kan beregne størrelsen af bc, ved at sigte fra $\mathrm{d}$ (øjet) og indsætte en målepind kf. Da alle størrelser dc, $\mathrm{kf}$ og df er kendte, kan vi beregne bc, fordi trekanterne bod og kdf er ensvinklede.

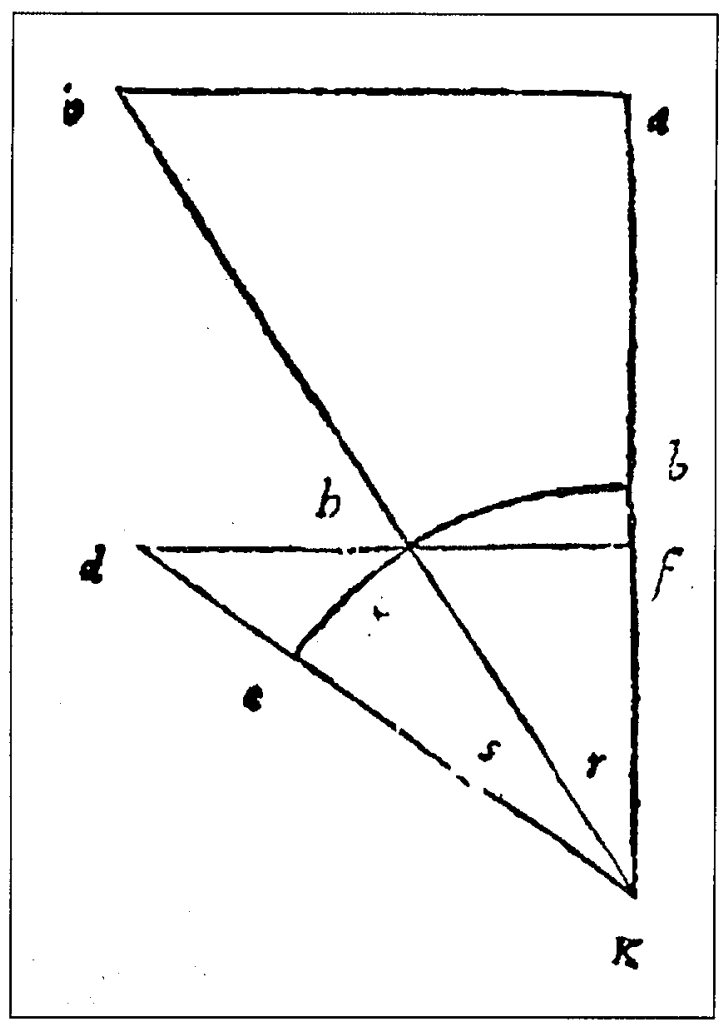

Fig. 13.

Illustration af Euklid's sætning fra en udgave af Optikken (samme udgave) der siger at ba og df ikke vil opleves i forhold til deres respektive afstande fra øjet $\mathrm{K}, \mathrm{Ka}$ og Kf, men derimod ved forholdet mellem vinklerne bKa (eller bue $\mathrm{hKl}$ ) og dKf (eller bue eKI). 
skue både museumsopstillingen og kompensere for den ud fra en vurdering af skulpturens emotionelle budskab.

Hvis vi da forfølger Kenneth Clarks argumentation om at matematikken har en betydning for udformningen af positioneringen af skulptur - og ligeså vel har en betydning for etableringen af forhold mellem hoved, hænder, arme, ben i det for beskueren uanset positioneringen af den. Står den lavt skal proportionerne kunne identificeres lige så godt som hvis de er tillagt en figur, der er placeret i et gavlfelt eller på en metope.

Og så vil det være fornuftigt at lade en af de helt store matematikere blande sig i diskussionen.

Grækerne er stadig berømte for deres matematik - den abstrakte matematik. Det er stadigvæk Euklids Elementerne der er den mest læste bog i den vestlige del af verden, men hans Optikken er ikke så populær. Der er også meget stor forskel. Bland andet den simple - at han ikke bruger den samme type matematik til at måle faktiske afstande og til at beskrive hvorledes afstande opleves af synet. Her "måler" synet ved forholdet mellem synsvinkler.

Hvad havde været nemmere end at sige: den og den genstand skal proportionalt formindskes med en halv en kvart en ottendedel, hvis den skal ses på denne eller hin afstand? Men så enkelt synes det ikke at være udført i den kunstneriske praksis. En genstand ser selvfølgelig mindre ud jo længere væk den er, dette forhold kan blot ikke omsættes i simple proportioner. Vi estimerer. Det er Euklid udmærket klar over, som det fremgår af Optikken. Og formentlig derfor bygger han hele Optikken op på grundlag af denne erfaring.

Euklid beskriver derfor vore synssansninger $i$ forhold mellem uligheder (større end/mindre end), ikke beregning i tal/geometriske proportioner. Proportioner indgår $\mathrm{i}$ arkitektens eller ingeniørens arbejde, når der skal måles hvor langt eller hvor stort i nøjagtigt mål. Øjet kan i den sammenhæng udmærket bruges som hjælpeinstrument, når der skal sigtes efter punkter i synsfeltet, for at beregne afstande. ${ }^{27}$ Men drejer det sig om en beskuer i forhold til f.eks. en skulptur, så bruger Euklid forholdet mellem synsvinkler. Og det markeres fra første side i $O p$ tikken.

Hvis man nemlig stiller sig den opgave at vurdere to lige store genstande (eksemplet er to lige store og parallelle størrelser i forskellig afstand fra øjet), så ses de $i k k e$ i forhold til deres afstande..$^{28}$ Måske er op tiske korrektioner i skulpturen så

27. Bøggild og Marcussen, Rumperception og Rumkonstruktion, 34 .

28. Ibid., 27 f., og Marcussen, Rumkonstruktioner, 5 I. 
at stille sig en anden opgave end at måle, altså ikke den først at etablere de målelige mål for derpå at omgøre dem til uligheder, men måske tænke i uligheder.

Man kan da gøre følgende tankeeksperiment: her er en mand med ideale proportioner, der skal ses som idealt skøn fra en positionering højt oppe.

Hvis vi derfor tænker os at vi har navlen siddende midt i (mands)kroppen, som Vitruvius angiver, så skal, som I 2 meter oppe på metoperne på Partbenon, det stykke, der er over navlen ses lige så stort ud som det under. Efter Euklid ser ting lige store ud hvis de ses under samme vinkel. ${ }^{29}$ Så hvis størrelse a ses under vinkel A, skal størrelse b også ses under denne vinkel. I følge denne tankegang må b gøres større end a for at se lige så stor ud (i samme plan må man så tilføje). Der er ikke nogen fuldstændig silkkerhed for, hvorledes Euklid's tekst skal fortolkes, men denne argumentation kan forhåbentlig accepteres som en stærkt skematiseret fortolkning.

Der er dog mange andre faktorer, der kan kompensere for skulpturens positionering: relieffet er dybere (Parthenon) i den øverste del end i den nederste altså giver lys og skyggevirkningen sit, men hvor meget denne virkning influerer på oplevelsen af størrelsen vil sikkert variere i forhold til forskellige typer af placering. Og hvad dette forhold bidrager til i forhold til skønheden er også uklart, men det emotionelle og dermed det levende kan givetvis fremhæves på denne måde. Desuden kan selve reliefpladen være tippet i forhold til vederlaget. Dermed vil størrelserne indeholdt $\mathrm{i}$ vinklerne komme tættere på hinanden.

Selve det statiske vil da formentlig være $\mathrm{i}$ balance, fordi relieffet er mindre udhugget forneden, hvor stenen så er tungest og mere frihugget og lettere foroven..$^{30}$ Jeg må tilstå at jeg ikke konkret ved i detaljer hvorledes det er udført i praksis og derfor burde jeg måske slet ikke have givet et besyv. Jeg peger på disse faktorer, fordi de vidner om helt igennem planlagte og beregnede forhold omkring kropsdimensioner og synspositioner - og skønhedsideal. Det synes derfor rimeligt, ud fra Kenneth Clarks indsigtfulde observationer, at inddrage Aristoteles'

29. Bøggild og Marcussen, Rumperception og Rumkonstruktion, 2 I. Vitruvius, De Arcbitectura (Como I 52 I, reprint London I 968), liber III, XLVIII ff. I denne udlægning er der to varianter af mandsfiguren, den ene indsætter en stående mand med samlede ben og armene rakt $9 \circ$ grader ud fra skuldrene $i$ et kvadratnet. Her ligger midten af manden i diagonalernes skæringspunkt, og disse rammer kønsdelene. I den anden er mandens ben spredte og armene rakt opad, således at fødder og hænder kan røre et kvadrats omskrevne cirkel. Her ligger diagonalernes skæringspunkt i navlen. Halvdelen af en stående mands højde fra hoved til fod ligger således ved kønsdelene.

30. Kiilerich, Gresk Skulptur, $x 26 \mathrm{f}$. 

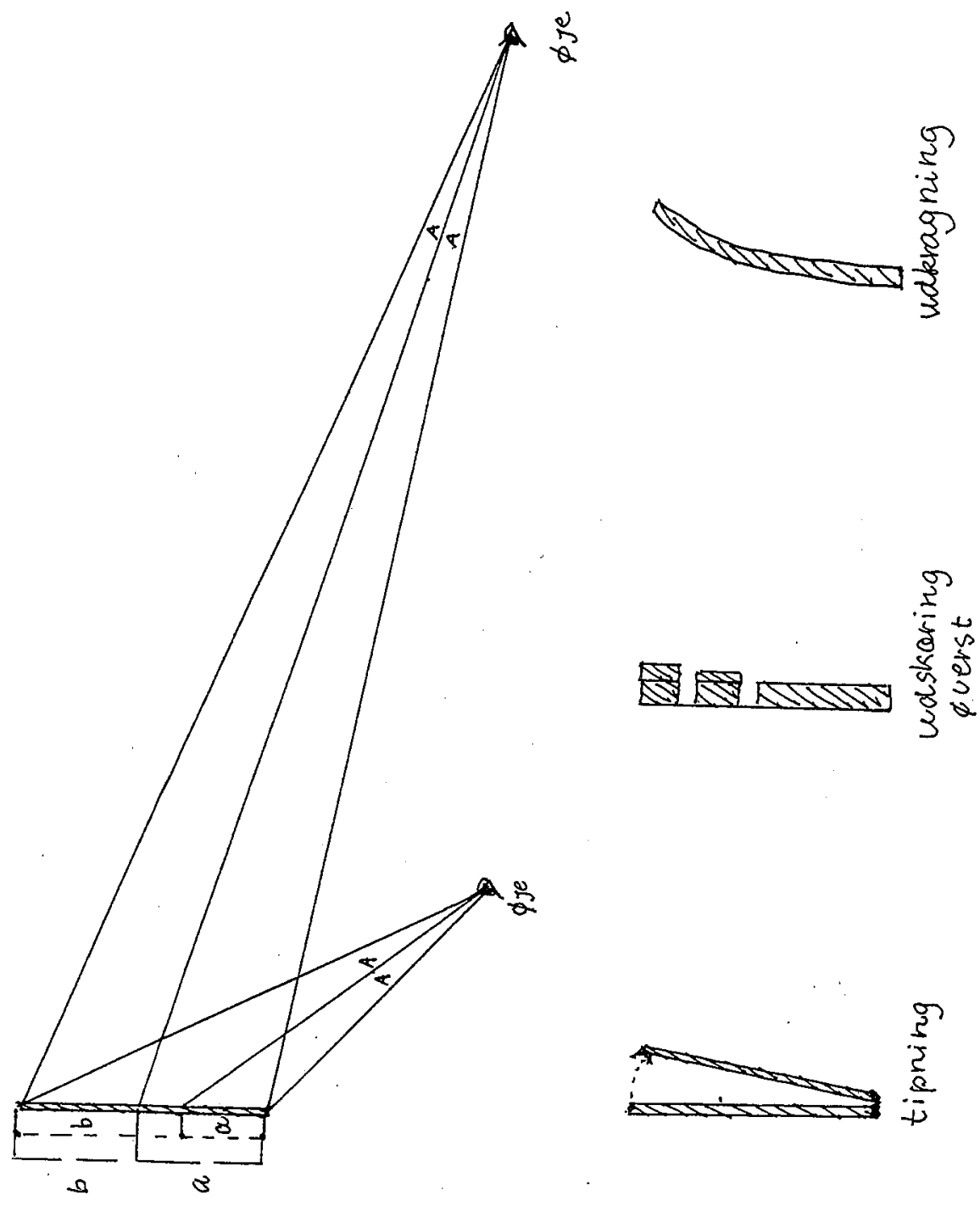

Fig. I 4: De skraverade felter forestiller en skupltur i profil. Øverst ses hvorledes en skulptur må korrigeres i størrelse afhængig af beskuerens position, nederst hvorledes tipning, udskæring af stenen samt udkragning kan bidrage til at skulpturen ses med naturlige proportioner.

Fig. I5.

Døende kriger, gavlfigur fra Aphaia-templet, Aigina, senarkaisk/tidlig klassisk tid, ca. 480 f.Kr. Pinakoteket, München. 


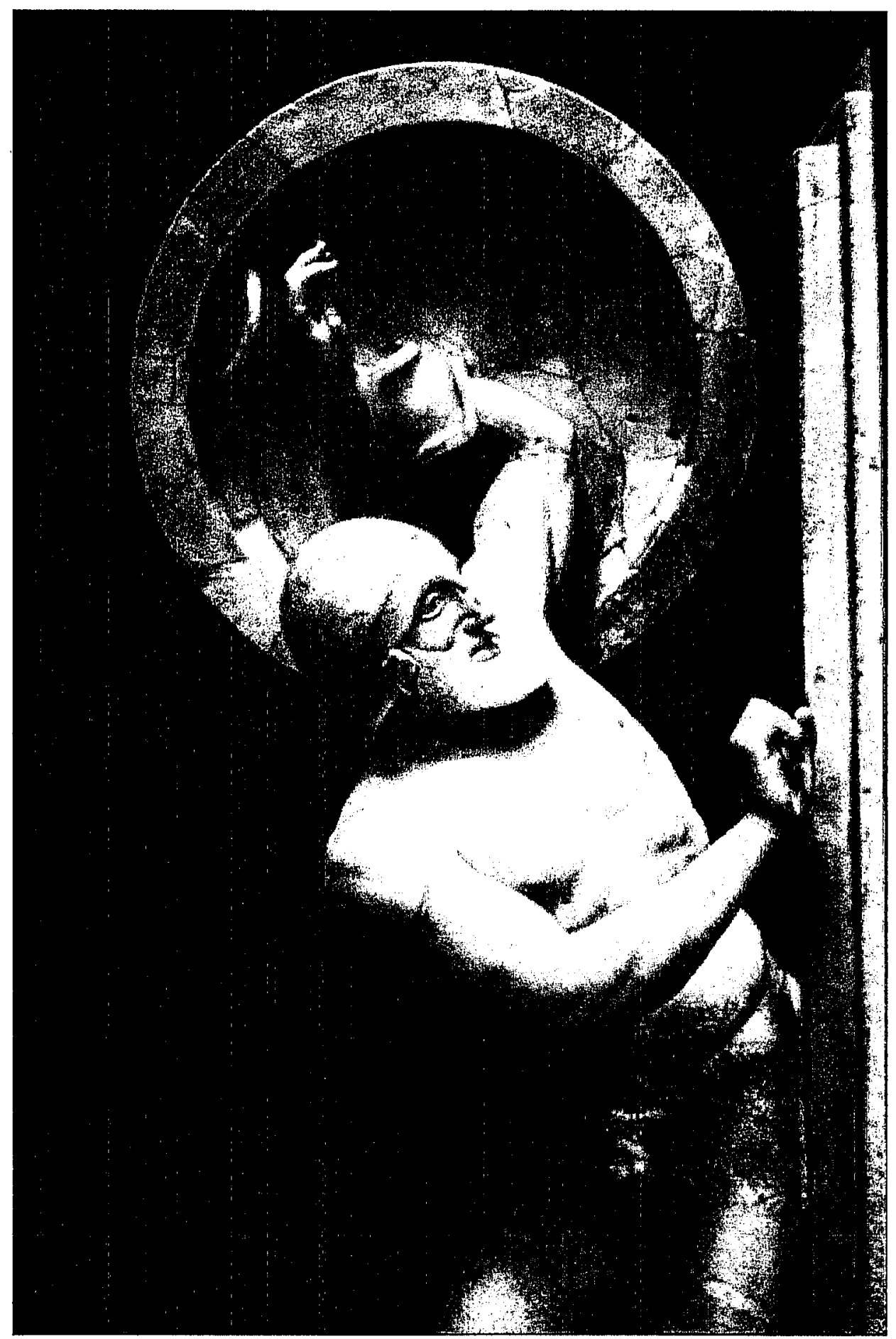


distinktion mellem to adskilte matematiske tænkemåder: den abstrakte matematik, som er Elementerne og i den anvendte matematik som er Optikken.3.

\section{Det skønne ideal og fremtiden}

Nu er spørgsmålet om det levende, det skønne ideal, proportionerne i dette og disse tings forhold til synet - repræsenteret ved en beskuer sat i spil - og en lang række overvejelser er nødvendige fremover, for at forsøge at udrede de konkrete forhold i fremstillingen af skulpturerne $i$ forhold til fremtrædelsen for synet. Krævende fordi disse ting skal tænkes for hver enkelt skulptur vi anskuer. Og måske er den eneste fremkommelige måde at forsøge sig med avanceret IT-modellering, for at gennemprøve en lang række positioneringer af udvalgte skulptureksempler. I alle tilfælde kan vi ikke undlade at fokusere på to forskellige matematiske tænkemåder kombineret med en æstetisk formel og en kognitiv/ perceptuel på een gang.

Dette fordrer at vi skal måle på selve figurerne og ikke kun kan være overladt til kameraet og dermed til det perspektiviske syn. Museumsfolk vil være bekymrede, men igen: nye teknikker kan gøre dette - og et undersøgelsesfelt for dine teorier Göran må være undervejs i en ny tid..$^{22}$ Det er inspirerende. Der peges på det enkle forhold at de kunstværker, der er opstillet i museerne ofte er placeret så de ser definitivt anderledes ud end på deres oprindelige plads i arkitektur eller $i$ et andet placeringsrum. Nogle af dem har vi muligheder for at vurdere, f.eks. Parthenonskulptureme, fordi der er en del tilbage in situ. Også Aiginagavlene kan man danne sig et begreb om, bl.a. i Afstøbningssamlingen i København. Her ses tydeligt at man tipper figurerne ud over gavlkanten for at vise fødder og ben. Men desuden, som jeg havde lejlighed til at måle efter - uden at røre - det bageste ben er længere end det forreste - og kraftigere - for at kompensere for afstanden. Så forkortningerne ændrer de faktiske - skønne - mål eller proportioner, for at de fra beskuerens position kan se både skønne og levende ud.

Det peger på, at hver eneste hugning af en skulptur må tænkes ud fra en lang række præmisser, som: forkortning, synsposition (høj, lav og i hvilken kontekst af andre skulpturer), foran, bagved - og det skønne ideal. Men forudsætningen

3I. Se note I2.

32. Denne teknik benyttes af mange kopister og må siges at være ganske både tidsbesparende og nøjagtig. På Westphalisches Universität Münster arbejdes med ARTIS Kopiertechnik (oplysningerne stammer fra en artikel i universitetets kalender for I999, for måneden januar 2000!). 
for det, ligger i bl.a. en nuanceret forståelse af vor perception, dels som den forklares i perioden frem til klassisk tid, dels som vi forstår den som moderne beskuere. Derfor må de mål der for kunstneren danner grundlaget for at hugge en skulptur efter det skønne ideal på denne måde også være fæstet i den antikke videnskabs distinktion mellem abstrakt og anvendt matematik, dvs. mellem den abstrakte matematiks proportions-tænkning og synets uligheds-tænkning. 